\title{
Salivary Diagnostics in Pediatrics: Applicability, Translatability, and Limitations
}

\author{
Mona Hassaneen ${ }^{1}$ and Jill L. Maron ${ }^{1,2 *}$ \\ ${ }^{1}$ Mother Infant Research Institute at Tufts Medical Center, Boston, MA, USA, ${ }^{2}$ Division of Newborn Medicine, \\ Floating Hospital for Children at Tufts Medical Center, Boston, MA, USA
}

In the last decade, technological advances, combined with an improved appreciation of the ability of saliva to inform caregivers about both oral health and systemic disease, have led to the emergence of salivary diagnostic platforms. However, the majority of these assays have targeted diseases that more commonly affect the adult population, largely neglecting infants and children who arguably could benefit the most from non-invasive assessment tools for health monitoring. Gaining access into development, infection, and disease through comprehensive "omic" analyses of saliva could significantly improve care and enhance health access. In this review, we will highlight novel applications of salivary diagnostics in pediatrics across the "omic" spectrum, including at the genomic, transcriptomic, proteomic, microbiomic, and metabolomic level. The challenges to implementing salivary platforms into care, including the effects of age, diet, and developmental

Edited by:

Paul Desmond Slowey, Oasis Diagnostics, USA

Reviewed by: Angelo D'Ambrosio, University of Turin, Italy Michael Noll-Hussong, University of UIm, Germany

*Correspondence: Jill L. Maron jmaron@tuftsmedicalcenter.org

Specialty section: This article was submitted to Digital Health,

a section of the journal Frontiers in Public Health

Received: 12 September 2016 Accepted: 03 April 2017 Published: 20 April 2017

Citation:

Hassaneen M and Maron JL (2017) Salivary Diagnostics in Pediatrics: Applicability, Translatability, and Limitations.

Front. Public Health 5:83. doi: 10.3389/fpubh.2017.00083 stage on salivary components, will be reviewed. Ultimately, large-scale, multicenter trials must be performed to establish normative biomarker values across the age spectrum to accurately discriminate between health and disease. Only then can salivary diagnostics truly translate into pediatric care.

Keywords: saliva, diagnostics, pediatrics, newborns, genetics

\section{INTRODUCTION}

Serum biomarkers have long been the gold standard for diagnostic testing (1-6). However, in recent years, advances in biotechnology, combined with a clinical demand for more user-friendly and noninvasive platforms, have led to the emergence of salivary diagnostic assays to better monitor disease, infection, and development (7-11). Perhaps, no other patient population could benefit more from these advances than pediatrics. The avoidance of serial phlebotomy for monitoring our most at-risk patients reduces trauma and limits anemia $(12,13)$. Further, as national and international organizations, such as the United States Food and Drug Association (USFDA) now mandate enrollment of children in clinical trials, assays that do not rely on invasive blood sampling offer a safer, more appealing alternative (14-16). While the benefits of salivary analysis in the pediatric population are plentiful, translating assays into clinical care remains a challenge. Salivary assay development for the adult population has seen exponential growth in recent decades, while diagnostics that aim at the unique diseases and conditions affecting infants and children lag significantly behind (Figure 1). Defining the clinical significance of individual variations in biomarker levels, determining thresholds that clearly discriminate between health and disease, and understanding the impact of age, diet, and development on the composition of saliva present hurdles to implementation. Nevertheless, a 


\section{Salivary Biomarkers Research}

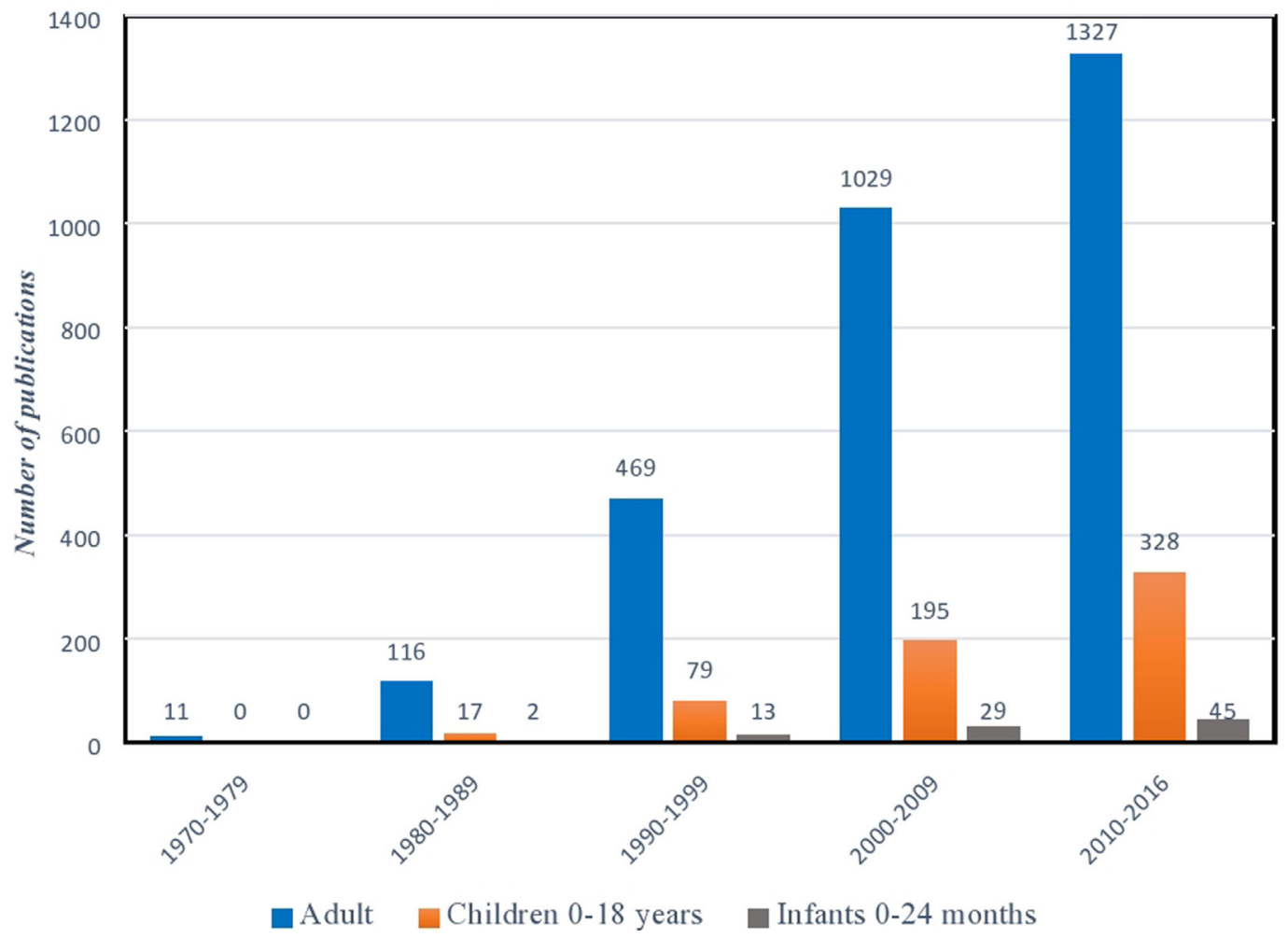

FIGURE 1 | Histogram illustrating exponential growth of salivary diagnostic platforms over time. Though the number of assays designed for children and infants has also increased, there remains a relative paucity of platforms targeted for this age demographic. (Data derived from a PubMed search 9.9.16: keywords "salivary biomarkers"; limits: humans.)

wealth of information can be gained from a mere drop of human saliva. From predicting physiological development and biological functions, to microbial and metabolic analyses, saliva is providing pediatric caregivers and researchers with an exciting new tool for exploration $(9,17-21)$.

In this review, we will highlight novel applications of salivary analyses across the "omic" spectrum, including at the genomic, transcriptomic, proteomic, metabolomic, and microbiomic level. The important impact of age and development on saliva components will be reviewed, and specific attention will be given to emerging platforms for use in both neonatal and pediatric populations. Limitations to assay development and clinical implementation will be discussed to further our understanding of both the applicability and the translatability of salivary diagnostics in the pediatric population.

\section{SALIVARY VARIATION ACROSS THE PEDIATRIC AGE SPECTRUM}

Though largely composed of water, human saliva contains electrolytes, microorganisms, enzymes, proteins, immunoglobulins, nucleic acids, enzymes, hormones, mucins, and drugs (22-24). Commercially available collection and stabilizing kits (e.g., DNA Genotek, Oasis Diagnostics ${ }^{\circledR}$ ) allow for both ease of collection and stabilization of constituents, often for weeks at a time at room temperature. These components, whether molecule, transcript, protein, metabolite, or microbe, are reflective of both the age and developmental stage of the individual (25-27). For example, salivary enzymes, such as amylase, are known to increase from early infancy through adolescence, ultimately peaking in adulthood (28-31). Salivary electrolyte levels are also known to vary with age. Calcium and magnesium are significantly higher in infancy compared to later in life; sodium to potassium ratios reach their highest levels in adolescence, likely corresponding to aldosterone surges associated with puberty (22). Such analyte concentration variability presents both opportunities and challenges for the investigator. The ability to non-invasively monitor growth and development, in real time, provides great promise (Figure 2). However, an investigator must be aware of biological changes that occur with age, as well as unique patient populations and situations, which may directly affect the oral cavity and its constituents, ultimately impacting the reliability and applicability of salivary assays.

There are critical environmental and developmental changes that take place in early life that also have a direct impact on saliva. For infants born prematurely ( $<37$ weeks' gestation), not only may the ongoing development of salivary glands impact filtration, secretion, and diffusion of molecules into saliva 


\begin{tabular}{|c|c|c|c|}
\hline & & Blood & Saliva \\
\hline \multirow{6}{*}{ 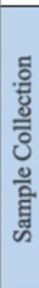 } & Noninvasive method of collection & & $\begin{array}{c}\mathbf{X} \\
\text { Noninvasive platform that can be used to monitor disease, infection and development }(7-11)\end{array}$ \\
\hline & Traumatic and noxious & $\mathbf{x}$ & Serial phlebotomy can increase risk of anemia during monitoring at-risk patients (12-16) \\
\hline & Painful & $\mathbf{X}$ & Ideal for fragile patient population e.g. Neonates $(12,13)$ \\
\hline & $\begin{array}{l}\text { User friendly, Ideal for challenging } \\
\text { clinical environments }\end{array}$ & & $\begin{array}{c}\mathrm{X} \\
\text { Portable testing kit with minimal professional training that can be used in developing countries, suburban } \\
\text { and rural areas. }\end{array}$ \\
\hline & Contagiousness hazard of pathogens & $\mathbf{X}$ & Ideal for pathogens that have contagiousness hazard during handling by health professionals e.g. HIV \\
\hline & Standardized collection methods & $\mathbf{X}$ & \\
\hline \multirow{4}{*}{ 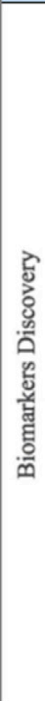 } & Biological variability of biomolecules & & $\begin{array}{c}\mathbf{X} \\
\text { Salivary components (molecule, transcript, protein, metabolite, and microbe) are reflective of both the } \\
\text { age and developmental stage of the individual }(26-28)\end{array}$ \\
\hline & $\begin{array}{l}\text { Validated normative values that } \\
\text { discriminate between health and } \\
\text { disease }\end{array}$ & $\mathbf{x}$ & Recent studies showed salivary glucose levels as a surrogate for blood levels $(76,78)$ \\
\hline & $\begin{array}{l}\text { Diagnostic applications across the } \\
\text { OMICs spectrum }\end{array}$ & $\mathbf{X}$ & 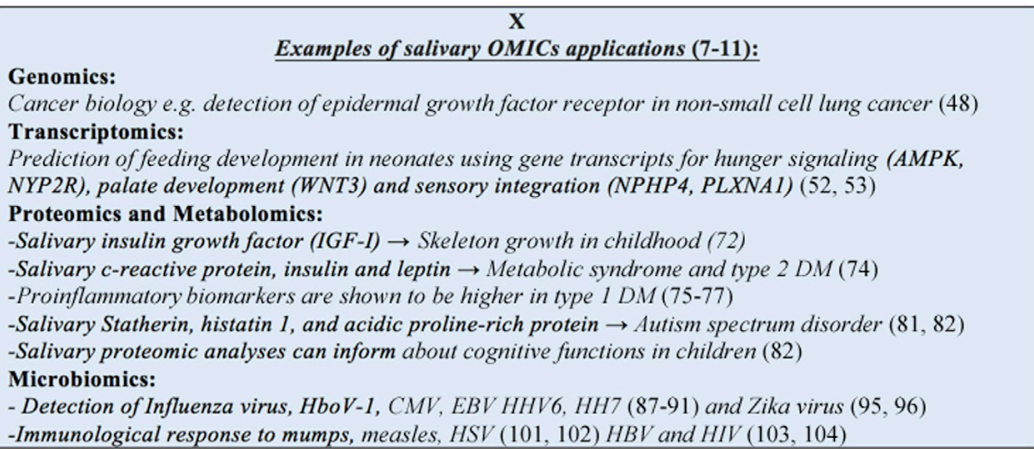 \\
\hline & $\begin{array}{l}\text { Potential for having Point-Of-Care } \\
\text { Testing (POCT) for global studies (17- } \\
\text { 22) }\end{array}$ & & $\mathbf{X}$ \\
\hline
\end{tabular}

FIGURE 2 | Benefits and limitations of saliva as a biofluid for biomarker discovery compared to serum, plasma, or whole blood.

(32) but also mode of birth (cesarean vs. vaginal), initiation of feeds, and type of nutrition (breast milk vs. formula), may directly affect microbial colonization and diversification in the oral cavity. In recent years, multiple investigators have begun to describe and highlight the rapid microbial colonization of the human shortly after birth (33-35). Deviations from normal deliveries, delays in the initiation of enteral nutrition, and prolonged hospitalizations are now known to significantly impact colonization of the gastrointestinal (GI) system (36-38). As the entry point to the GI system and a critical player in overall GI health, saliva undoubtedly is equally affected by these variables. In addition, studies have shown a significant increase in oral microbial colonization and taxa variability as an infant grows and develops (39). Teeth eruption during the first few months to years of life and exposure to solid foods are considered to be the major contributors to this variability $(39,40)$. Oral bacteria that reside in gingival crevices and around teeth begin to emerge with tooth eruption. In parallel, both albumin and immunoglobulin (Ig) $G$ levels rise in saliva with increasing mucosal permeability (41). Further, studies have shown that with the introduction of solid foods, salivary peptidomal profiles are altered (39) and Ig levels shift from non-specific innate immunity to specific immune response elements, e.g., $\operatorname{IgA}$ and $\beta-2$ microglobulin of MHC class I. These alterations are believed to reflect the development of adaptive immune responses after exposure to different noxious dietary and environmental substances (39,
40). These age-specific differences remind investigators that they must consider the developmental stage of an individual when designing and importantly, interpreting salivary assays. Normative values and microbial diversification will vary with age, and assay interpretation must reflect these findings appropriately.

\section{SALIVARY "OMICS"}

\section{Salivary Genomics}

The oral cavity, though not saliva in particular, has offered caregivers a direct, non-invasive source of genomic material. In recent years, genetic testing has moved away from reliance upon invasive blood sampling toward user-friendly buccal swabs $(42,43)$. From commercially available at-home genetic testing kits (e.g., http://23andme.com, http://Ancestry.com) to paternity testing in the NICU, the ease with which sufficient quality and quantity of DNA samples can be obtained has markedly improved (43). However, beyond cellular DNA which is best harvested through cells, saliva is likely a rich source of cell-free and exosomal DNA that may provide caregivers with specific opportunities to monitor the overall health of the individual and further explore cell-to-cell communication (44-46). While research in this area continues to emerge, it is easy to see its applicability to child health. Genomic analysis of plasma cell-free DNA is directly impacting the field of cancer biology (47). Oncologists may now monitor the genomes 
of cell-free tumor DNA in plasma samples in order to generate targeted and personal therapies, assess drug resistance, and monitor a patient's response to therapy by quantitative analysis of tumor load. Analysis of salivary cell-free DNA may provide similar insight and be highly beneficial in children affected by cancer who are already undergoing countless needle sticks and invasive procedures. Indeed, $\mathrm{Pu}$ et al. have recently demonstrated the applicability of a salivary assay for the detection of a genomic deletion in the epidermal growth factor receptor in patients with non-small cell lung cancer (48). While future studies are needed to demonstrate the role of cell-free salivary DNA in child health, it nevertheless offers yet another opportunity to improve delivery of care in this vulnerable population.

\section{Salivary Transcriptomics}

Our laboratory was one of the first to publish real-time developmental information available at a transcriptomic (RNA or gene expression) level in the newborn (49-51). In our original article, we demonstrated that transcripts, indicative of all major organ systems, were readily detected in an infant's mouth (49). Genes identified were known to play a role in the developing GI, nervous, and hematological systems. While the trafficking mechanisms of these gene transcripts remain largely unknown, these initial hypothesis discovery experiments led to a series of targeted assays aimed at better defining developmental milestones and phenotypes.

Using high-throughput screening tools, such as multiplexed reverse transcriptase-quantitative polymerase chain reaction, on total RNA extracted from as little as $5 \mu \mathrm{L}$ of neonatal saliva, we have been able to identify a panel of genes whose combined expression profiles may help neonatal caregivers to objectively assess oral feeding skills $(52,53)$. Genes identified on the panel are involved in diverse biological functions including hunger signaling (AMPK, NYP2R), palate development (WNT3), and sensory integration (NPHP4, PLXNA1). In initial studies, the combined salivary expression profile of these biomarkers was shown to be up to $78 \%$ accurate in predicting mature oral feeding skills in the newborn. In addition, our laboratory has been the first to link expression levels of a well-described speechlanguage gene, FOXP2, to oral feeding success in the newborn $(54,55)$. These experiments have laid the foundation for future studies to non-invasively explore developmental biology in our youngest patients and offer caregivers an enormous opportunity to utilize salivary transcriptomics to further explore, diagnose, and potentially prevent other areas of neonatal pathology where disrupted development results in unique and often lifethreatening diseases including bronchopulmonary dysplasia, necrotizing enterocolitis (NEC), or retinopathy of prematurity. However, as a newly emerging field, it is important to recognize the potential impact of growth and biology on assay applicability. As stated previously, defining normative values across the age spectrum, exploring sex differences in expression patterns, understanding the role of salivary gland development, microbial colonization patterns, diet, and tooth eruption on gene expression will take prospective, collaborative, multicenter trials. Failing to perform the necessary experiments, such as observational studies to examine developing microbial colonization patterns or to establish normative reference genes for appropriate gene expression analyses over time, will directly impact our ability to translate these exciting discoveries to the bedside.

\section{Salivary Proteomics and Metabolomics}

Saliva has been estimated to contain approximately 2,000 peptides, comprising $40-50 \%$ of total secreted body proteins (56). Unlike nucleic acids (DNA and RNA) that traditionally require the additional step of extraction prior to analysis, salivary proteins may be detected and quantified directly after collection. This ease of processing, combined with their relative stability compared to either DNA or RNA, makes proteins ideal biomarkers. Recent advances in technology and bioinformatics has allowed for the comprehensive profiling of hundreds to thousands of proteins from a single sample source to improve our understanding of the physiological, as well as the pathological, status of the human being (57-61).

To date, salivary protein biomarkers have been described for multiple adult oral and systemic diseases, including breast, pancreatic, and oral cancers (62-65), as well as autoimmune diseases, such as Sjögren's disease, diffuse systemic sclerosis, rheumatoid arthritis, and systemic lupus erythematosus (SLE) (66). Moreover, studies have investigated the role of salivary proteomic analyses to predict myocardial infarction, diabetes mellitus types 1 and 2 , and pulmonary diseases (67-69). While the pediatric patient population is ripe for similar diagnostic advances, here too, an investigator must pay specific attention to unique circumstances, including ongoing and rapid development as well as hormonal changes associated with puberty, which may impact proteomic analyses in newborns, infants, and children.

The salivary proteome varies from childhood to adolescence and is often dependent upon growth (70-72). For example, concentrations of salivary insulin growth factor (IGF-I) may vary and serve as an indicator of skeletal growth throughout childhood (71). Nutritional status of the child also affects salivary biomarkers. Malnourished children have specific salivary proteomic variations associated with protein energy under nutrition or PEU (73), and children affected with type 1 diabetes have been shown to have higher levels of salivary pro-inflammatory biomarkers compared to healthy controls. Conversely, there is a growing body of research examining salivary metabolomics that may predict metabolic syndrome, type 2 diabetes, and obesity in children. A recent study of 744 children (age 11) showed that salivary levels of c-reactive protein, salivary insulin, and leptin were higher and adiponectin levels lower in obese children compared to healthy normal weight children (74). Other studies tested the applicability and reliability of using salivary glucose levels as a surrogate for blood levels (75-77). With the use of a regression equation, salivary glucose values could accurately be converted to blood glucose levels, providing patients, especially children with type 1 diabetes, with a non-invasive tool for selfmonitoring (78).

Beyond assessing the nutritional and metabolic status of children, there have been a limited number of studies utilizing salivary proteins for disease detection in this population. Salivary biomarkers for familial juvenile SLE, a more aggressive form 
of the disease known to causes widespread tissue damage and inflammation, have been described (79). Interestingly, there have also been recent studies showing aberrant protein expression in the saliva of children affected with autism spectrum disorder. Research has shown that there are decreased levels of three proteins, statherin, histatin 1 , and acidic proline-rich protein, in the saliva of autistic children compared to healthy controls $(80,81)$. In addition, Wormwood and colleagues have recently demonstrated that salivary proteomic analyses of children can inform caregivers about developing cognitive functions (82). The ability of saliva to provide a window into disrupted neurodevelopment holds enormous promise for the field, allowing caregivers insight into areas of the body once believed only to be accessible though costly neuroimaging (e.g., MRI, CT) or invasive procedures (e.g., cerebral spinal fluid, blood).

\section{Salivary Microbiomics and Metagenomics}

According to the World Health Organization, infectious diseases are the leading cause of death of children and adolescents worldwide (83). Improved methods for earlier detection of infections, particularly in developing nations where blood sampling is not only invasive but also impractical, holds the potential for significantly improving outcomes. While the healthy human mouth contains as many as 500 million bacterial cells with more than 700 different colony species (84-86), it can also harbor and shed pathological infections. Upper respiratory infections, such as the influenza virus and human bocavirus $\mathrm{HboV}-1$, a mild respiratory disease, can be detected in the saliva up to 1 year after primary infection $(87,88)$. In addition, cytomegalovirus (CMV), EpsteinBarr virus, human herpes virus (HHV) 6, and HHV7 can all be detected in human saliva (89-91). CMV, the most common cause of congenital hearing loss in children in developed countries (92), was one of the first viruses to be successfully detected through salivary analysis in the newborn (93). These initial reports showed not only that the virus was as readily detectable in saliva compared to more traditional assays using urine but also that saliva had a higher sensitivity for CMV detection compared to blood (94). Most recently, saliva has been shown to be an important biofluid for monitoring infectious Zika virus particles $(95,96)$. Salivary assays aimed at Zika RNA detection may prove to be a valuable tool for caregivers who are tracking exposure rates, transmission, and shedding of the virus.

In addition to the specific microbial detection, saliva also contains $\operatorname{IgA}$, IgM, and IgG, which can assess immunological status and response to infection (97). For instance, studies have reported both the detection of specific antibodies to rotavirus infection in saliva (98), as well as the immunological response after administration of the vaccine (99). Similarly, rubella-specific IgM antibodies are detectable in children's saliva (100), as are IgG levels of children who are seropositive for mumps, measles, and the herpes simplex virus $(101,102)$. Moreover, the hepatitis $\mathrm{B}$ virus, human immunodeficiency viruses, and Salmonella typhi can all be identified through the use of advanced technological approaches for Ig detection in the salivary fluid of children (103-105).
One of the more interesting aspects of working with saliva as a biofluid for clinical assessment is the fact that it harbors hundreds of organisms. In recent years, the field of metagenomics, defined as the genomes of all the organisms living in a specific environment in the human body, has emerged (106). Our ability to analyze not simply human gene and protein expression but also the organisms residing in the mouth that may be responsible for such a response, provides yet another opportunity to improve child health. Unique microbial colonization patterns have been shown to be associated with disease including childhood caries, NEC, and metabolic syndrome. Identifying aberrant microbial colonization patterns, while simultaneously monitoring an individual's unique immune and inflammatory response, may allow for the development of preventative strategies to improve health outcomes $(86,107)$.

\section{Other Considerations and Applications}

In 2014, the Centers for Disease Control reported that the prevalence of children $\geq 12$ years old using illicit drug was $12 \%$ (107), and the use of non-medical psychotherapeutic drugs was $2.5 \%$. Sadly, as drug abuse has become increasingly common, novel detection methods, including those that can be performed easily in the either home or office under direct visualization, are needed. Salivary drug screening assays have already been approved by the USFDA and are available for medical and commercial use (e.g., http://americanscreeningcorp.com). Cocaine, amphetamines, opioids, benzodiazepines, and tetra-hydro-cannabinoids, among others, can all be detected and quantified in saliva (108-111). Further, concentrations of drug metabolites of a variety of prescribed drugs are also measurable in saliva $(112,113)$, making ease of obtaining therapeutic levels without invasive, serial phlebotomy possible.

\section{CONCLUSION}

Salivary diagnostics are primed to have an important impact on infant and child health. Whether accessing the genome, exploring real-time gene and protein expression during development, or evaluating the metabolic and infectious status of the individual, applying the latest technological advances to salivary analysis can provide valuable insight into the health of the child in a safe, non-invasive manner. However, careful attention must be made to age, diet, and developmental stage when designing assays. Establishing normative values of gene and protein expression, as well as metabolites and microbes, to account for normal variations across the age spectrum can only be achieved through prospective, large-scale, multicenter trials. Only then can data be interpreted appropriately and the hope of translating salivary diagnostic into pediatric carefully realized.

\section{AUTHOR CONTRIBUTIONS}

JM conceived of, wrote, and edited this review. $\mathrm{MH}$ wrote and edited this review. Please note: JM is the senior and last author on this manuscript. 


\section{REFERENCES}

1. Benito J, Acedo Y, Medrano L, Barcena E, Garay RP, Arri EA. Usefulness of new and traditional serum biomarkers in children with suspected appendicitis. Am J Emerg Med (2016) 34:871-6. doi:10.1016/j.ajem.2016.02.011

2. Wang H, Hu J, Chen L. Decreased serum miR-503 level in children with nephrotic syndrome. Clin Lab (2015) 61:1917-26. doi:10.7754/Clin. Lab.2015.150407

3. Odera G, Vaira D, Holton J, Dowsett JF, Ansaldi N. Serum pepsinogen I and $\mathrm{IgG}$ antibody to Camplylobacter pylori in non-specific abdominal pain in childhood. Gut (1989) 30:912-6. doi:10.1136/gut.30.7.912

4. Scheuring U, Skopnik H, Roth B, Uhlenbruck G, Metzgar RS. Analysis of pancreatic serum markers in patients with cystic fibrosis. Pancreas (1991) 6:229-33. doi:10.1097/00006676-199103000-00016

5. Keane M, Fallon R, Riordan A, Shaw B. Markedly raised levels of C-reactive protein are associated with culture-proven sepsis or necrotizing enterocolitis in extremely preterm neonates. Acta Paediatr (2015) 104:e289-93. doi:10.1111/apa.12978

6. Hedegaard SS, Wisborg K, Hvas AM. Diagnostic utility of biomarkers for neonatal sepsis - a systematic review. Infect Dis (2015) 47:117-24. doi:10.31 09/00365548.2014.971053

7. Zahng Y, Sun J, Lin CC, Abemayor E, Wang MB, Wong DT. The emerging landscape of salivary diagnostics. Peridontol 2000 (2016) 70:38-52. doi:10.1111/prd.12099

8. Bonne NJ, Wong DT. Salivary biomarker development using genomic, proteomic and metabolomic approaches. Genome Med (2012) 4:82. doi:10.1186/ gm 383

9. Schafer CA, Schafer JJ, Yakob M, Lima P, Camargo P, Wong DT. Saliva diagnostics: utilizing oral fluids to determine health status. Monogr Oral Sci (2014) 24:88-98. doi:10.1159/000358791

10. Javaid MA, Ahmed AS, Durand R, Tran SD. Saliva as a diagnostic tool for oral and systemic diseases. J Oral Biol Craniofac Res (2016) 6:66-75. doi:10.1016/j. jobcr.2015.08.006

11. Nunes LA, Mussavira S, Bindhu OS. Clinical and diagnostic utility of saliva as a non-invasive diagnostic fluid. Biochem Med (2015) 5:177-92. doi:10.11613/ BM.2015.018

12. Ranger M, Grunau RE. Early repetitive pain in preterm infants in relation to the developing brain. Pain Manag (2014) 4:57-67. doi:10.2217/pmt.13.61

13. Vinall J, Grunau RE. Impact of repeated procedural pain-related stress in infants born very preterm. Pediatr Res (2014) 75:584-7. doi:10.1038/ pr.2014.16

14. Institute of Medicine (US) Committee on Clinical Research Involving Children, Field MJ, Behrman RE, editors. Ethical Conduct of Clinical Research Involving Children. Washington, DC: National Academies Press (2004). 2, The Necessity and Challenges of Clinical Research Involving Children. Available from: http://www.ncbi.nlm.nih.gov/books/NBK25553/

15. Autmizguine J, Benjamin DK Jr, Smith PB, Sampson M, Overchkine P, Cohen-Wolkowiez $M$, et al. Pharmacokinetic studies in infants using minimal-risk study designs. Curr Clin Pharmacol (2014) 9:350-8. doi:10.217 4/1574884709666140520153308

16. U.S. Food and Drug Administration. Additional Protections for Children. (2001). Available from: http://www.fda.gov/ScienceResearch/SpecialTopics/ RunningClinicalTrials/ucm119111.htm

17. Baum BJ, Yates JR III, Srivastava S, Wong DT, Melvin JE. Scientific frontiers: emerging technologies for salivary diagnostics. Adv Dent Res (2011) 23:360-8. doi:10.1177/0022034511420433

18. Hart RW, Mauk MG, Liu C, Qiu X, Thompson JA, Chen D, et al. Pointof-care oral-based diagnostics. Oral Dis (2011) 17:745-52. doi:10.1111/j. 1601-0825.2011.01808.x

19. Wong DT. Salivomics. J Am Dent Assoc (2012) 143:19S-24S. doi:10.14219/ jada.archive.2012.0339

20. Lee YH, Wong DT. Saliva: an emerging biofluid for early detection of diseases. Am J Dent (2009) 22:241-8.

21. Segal A, Wong DT. Salivary diagnostics: enhancing disease detection and making medicine better. Eur J Dent Educ (2008) 12(Suppl 1):22-9. doi:10.1111/j.1600-0579.2007.00477.x

22. Humphrey SP, Williamson RT. A review of saliva: normal composition, flow, and function. J Prosthet Dent (2001) 85:162-9. doi:10.1067/mpr.2001. 113778
23. Carpenter GH. The secretion, components, and properties of saliva. Annu Rev Food Sci Technol (2013) 4:267-76. doi:10.1146/annurev-food-030212-182700

24. Drobitch RK, Svensson CK. Therapeutic drug monitoring in saliva: an update. Clin Pharmacokinet (1992) 23:365-79. doi:10.2165/00003088199223050-00003

25. Ben-Aryeh H, Fisher M, Szargel R, Laufer D. Composition of whole unstimulated saliva of healthy children: changes with age. Arch Oral Biol (1990) 35:929-31. doi:10.1016/0003-9969(90)90075-L

26. Salvolini E, Mazzanti L, Martarelli D, Di Giorgio R, Fratto G, Curatola G. Changes in the composition of human unstimulated whole saliva with age. Aging (1999) 11:119-22.

27. Redman RS. Development of the salivary glands. In: Sreebny LM, editor. The Salivary System. Boca Raton, FL: CRC Press (1987). p. 2-17.

28. Sevenhuysen GP, Holodinsky C, Dawes C. Development of salivary $\alpha$-amylase in infants from birth to 5 months. Am J Clin Nutr (1984) 39:584-8.

29. Rossiter MA, Barrowman JA, Dand A, Wharton BA. Amylase content of mixed saliva in children. Acta Paediatr Scand (1974) 63:389-92. doi:10.111 1/j.1651-2227.1974.tb04815.x

30. Yang Z-M, Chen L-H, Zhang M, Lin J, Zhang J, Chen WW, et al. Age differences of salivary alpha-amylase levels of basal and acute responses to citric acid stimulation between Chinese children and adults. Front Physiol (2015) 6:340. doi:10.3389/fphys.2015.00340

31. Chen LH, Yang ZM, Chen WW, Lin J, Zhang M, Yang XR, et al. Attenuated acute salivary $\alpha$-amylase responses to gustatory stimulation with citric acid in thin children. Br J Nutr (2015) 113:1078-85. doi:10.1017/ S0007114515000446

32. Castagnola M, Inzitari R, Fanali C, Iavarone F, Vitali A, Desiderio C, et al. The surprising composition of the salivary proteome of preterm human newborn. Mol Cell Proteomics (2011) 10:M110.003467. doi:10.1074/mcp.M110.003467

33. Nuriel-Ohayon M, Neuman H, Koren O. Microbial changes during pregnancy, birth, and infancy. Front Microbiol (2016) 7:1031. doi:10.3389/ fmicb.2016.01031

34. Rautava S. Early microbial contact, the breast milk microbiome and child health. J Dev Orig Health Dis (2016) 7:5-14. doi:10.1017/S2040174415001233

35. Munyaka PM, Khafipour E, Ghia JE. External influence of early childhood establishment of gut microbiota and subsequent health implications. Front Pediatr (2014) 2:109. doi:10.3389/fped.2014.00109

36. Dominguez-Bello MG, Costello EK, Contreras M, Magris M, Hidalgo G, Fierer $\mathrm{N}$, et al. Delivery mode shapes the acquisition and structure of the initial microbiota across multiple body habitats in newborns. Proc Natl Acad Sci U S A (2010) 107:11971-5. doi:10.1073/pnas.1002601107

37. Gronlund MM, Lehtonen OP, Eerola E, Kero P. Fecal microflora in healthy infants born by different methods of delivery: permanent changes in intestinal flora after cesarean delivery. J Pediatr Gastroenterol Nutr (1999) 28:19-25. doi:10.1097/00005176-199901000-00007

38. DiGiulio DB, Romero R, Amogan HP, Kusanovic JP, Bik EM, Gotsch F, et al. Microbial prevalence, diversity and abundance in amniotic fluid during preterm labor: a molecular and culture-based investigation. PLoS One (2008) 3:e3056. doi:10.1371/journal.pone.0003056

39. Morzel M, Jeannin A, Lucchi G, Truntzer C, Pecqueur D, Nicklaus S, et al. Human infant saliva peptidome is modified with age and diet transition. J Proteomics (2012) 75:3665-73. doi:10.1016/j.jprot.2012.04.028

40. Morzel M, Palicki O, Chabanet C, Lucchi G, Ducoroy P, Chambon C, et al. Saliva electrophoretic protein profiles in infants: changes with age and impact of teeth eruption and diet transition. Arch Oral Biol (2011) 56:634-42. doi:10.1016/j.archoralbio.2010.12.015

41. Lamster IB. Evaluation of components of gingival crevicular fluid as diagnostic tests. Ann Periodontol (1997) 2:123-37. doi:10.1902/annals.1997.2.1.123

42. Adriaanse MP, Vreugdenhil AC, Vastmans V, Groeneveld L, Molenbroeck S, Schott DA. Human leukocyte antigen typing using buccal swabs as accurate and non-invasive substitute for venipuncture in children at risk for celiac disease. J Gastroenterol Hepatol (2016) 31:1711-16. doi:10.1111/jgh.13331

43. Witsø E, Stene LC, Paltiel L, Joner G, Rønningen KS. DNA extraction and HLA genotyping using mailed mouth brushes from children. Pediatr Diabetes (2002) 3:89-94. doi:10.1034/j.1399-5448.2002.30205.x

44. Vandewoestyne M, Van Hoofstat D, Franssen A, Van Nieuwerburgh F, Deforce D. Presence and potential of cell free DNA in different types of forensic samples. Forensic Sci Int Genet (2013) 7:316-20. doi:10.1016/j. fsigen.2012.12.005 
45. Yao W, Mei C, Nan X, Hui L. Evaluation and comparison of in vitro degradation kinetics of DNA in serum, urine and saliva: a qualitative study. Gene (2016) 15:142-8. doi:10.1016/j.gene.2016.06.033

46. Tu M, Wei F, Yang J, Wong D. Detection of exosomal biomarker by electric field-induced release and measurement (ERIFM). J Vis Exp (2015) 95:52439. doi:10.3791/52439

47. Oxnard GR, Paweletz CP, Sholl LM. Genomic analysis of plasma cellfree DNA in patients with cancer. JAMA Oncol (2016). doi:10.1001/ jamaoncol.2016.2835

48. Pu D, Liang H, Wei F, Akin D, Feng Z, Yan Q, et al. Evaluation of a novel saliva-based epidermal growth factor receptor mutation detection for lung cancer: a pilot study. Thorac Cancer (2016) 7:428-38. doi:10.1111/1759-7714.12350

49. Maron JL, Johnson KL, Rocke DM, Cohen MG, Liley AJ, Bianchi DW. Neonatal salivary analysis reveals global developmental gene expression changes in the premature infant. Clin Chem (2010) 56:409-16. doi:10.1373/ clinchem.2009.136234

50. Maron JL. The neonatal transcriptome. Cold Spring Harb Perspect Med (2015) 6:a026369. doi:10.1101/cshperspect.a026369

51. Maron JL. Exploring the neonatal salivary transcriptome: technical optimization and clinical applications. Clin Biochem (2011) 44:467-8. doi:10.1016/j. clinbiochem.2011.03.019

52. Maron JL, Hwang JS, Pathak S, Ruthazer R, Russell RL, Alterovtiz G. Computational gene expression modeling identifies salivary biomarker analysis that predict oral feeding readiness in the newborn. J Pediatr (2014) 166:282-8. doi:10.1016/j.jpeds.2014.10.065

53. Maron JL, Johnson KL, Dietz JA, Chen ML, Bianchi DW. Neuropepetide Y2 receptor (NPY2R) expression in saliva predicts feeding immaturity in the premature neonate. PLoS One (2012) 7:e37870. doi:10.1371/journal.pone.0037870

54. Zimmerman E, Maki M, Maron J. Salivary FOXP2 expression and oral feeding success in premature infants. Cold Spring Harb Mol Case Stud (2016) 2:a000554. doi:10.1101/mcs.a000554

55. Zimmerman E, Maron JL. FOXP2 gene deletion and infant feeding difficulties: a case report. Cold Spring Harb Mol Case Stud (2016) 2:a000547. doi:10.1101/mcsa000547

56. Amado F, Lobo MJ, Domingues P, Duarte JA, Vitorino R. Salivary peptidomics. Expert Rev Proteomics (2010) 7(5):709-21. doi:10.1586/epr.10.48

57. Wei F, Wong DT. Point-of-care platforms for salivary diagnostics. Chin J Dent Res (2012) 15:7-15.

58. Spielmann N, Wong DT. Saliva: diagnostics and therapeutic perspectives. Oral Dis (2011) 17:345-54. doi:10.1111/j.1601-0825.2010.01773.x

59. Wong DT. Salivary diagnostics powered by nanotechnologies, proteomics and genomics. JAm Dent Assoc (2006) 137:313-21. doi:10.14219/jada. archive.2006.0180

60. Pasic MD, Yousef GM, Diamandis EP. The proteomic revolution in laboratory medicine. Clin Biochem (2013) 6:397-8. doi:10.1016/j.clinbiochem. 2013.02.012

61. Amado FM, Vitorino RM, Domingues PM, Lobo MJ, Duarte JA. Analysis of the human saliva proteome. Expert Rev Proteomics (2005) 2:521-39. doi:10.1586/14789450.2.4.521

62. Schulz BL, Cooper-White J, Punyadeera CK. Saliva proteome research: current status and future outlook. Crit Rev Biotechnol (2013) 33:246-59. doi: $10.3109 / 07388551.2012 .687361$

63. Hu S, Loo JA, Wong DT. Human saliva proteome analysis and disease biomarker discovery. Expert Rev Proteomics (2007) 4:531-8. doi:10.1586/ 14789450.4.4.531

64. John MA, Li Y, Zhou X, Denny P, Ho CM, Montemagno C, et al. Interleukin 6 and interleukin 8 as potential biomarkers for oral cavity and oropharyngeal squamous cell carcinoma. Arch Otolaryngol Head Neck Surg (2004) 130:929-35. doi:10.1001/archotol.130.8.929

65. Mishra S, Saadat D, Kwon O, Lee Y, Choi WS, Kim JH, et al. Recent advances in salivary cancer diagnostics enabled by biosensors and bioelectronics. Biosens Bioelectron (2016) 81:181-97. doi:10.1016/j.bios.2016.02.040

66. Hu S, Wang J, Meijer J, Ieong S, Xie Y, Yu T, et al. Salivary proteomic and genomic biomarkers for primary Sjögren's syndrome. Arthritis Rheum (2007) 56:3588-600. doi:10.1002/art.22954

67. Rahim MA, Rahim ZH, Ahmad WA, Hashim OH. Can saliva proteins be used to predict the onset of acute myocardial infarction among high-risk patients. Int J Med Sci (2015) 12:329-35. doi:10.7150/ijms.11280
68. Nicholas BL, Skipp P, Barton S, Singh D, Bagmane D, Mould R, et al. Identification of lipocalin and apolipoprotein A1 as biomarkers of chronic obstructive pulmonary disease. Am J Respir Crit Care Med (2010) 181: 1049-60. doi:10.1164/rccm.200906-0857OC

69. Hirtz C, Chevalier F, Sommerer N, Raingeard I, Bringer J, Rossignol M, et al. Salivary protein profiling in type I diabetes using two-dimensional electrophoresis and mass spectrometry. Clin Proteomics (2006) 2:117-27. doi:10.1385/CP:2:1:117

70. Cabras T, Pisano E, Boi R, Olianas A, Manconi B, Inzitari R, et al. Agedependent modifications of the human salivary secretory protein complex. J Proteome Res (2009) 8:4126-34. doi:10.1021/pr900212u

71. Nayak S, Bhad WA, Doshi UH. The relationship between salivary insulin-like growth factor I and quantitative cervical maturational stages of skeletal maturity. J Orthod (2014) 41:170-4. doi:10.1179/1465313313Y.0000000091

72. Messana I, Cabras T, Iavarone F, Manconi B, Huang L, Martelli C, et al. Chrono-proteomics of human saliva: variations of the salivary proteome during human development. J Proteome Res (2015) 14:1666-77. doi:10.1021/ pr501270x

73. Fonteles CS, dos Santos CF, da Silva Alves KS, de Miranda Mota AC, Damasceno JX, Fonteles MC. Comparative proteomic analysis of human whole saliva of children with protein-energy undernutrition. Nutrition (2012) 28:744-8. doi:10.1016/j.nut.2011.10.005

74. Shi P, Goodson JM, Hartman ML, Hasturk H, Yaskell T, Vargas J, et al. Continuous metabolic syndrome scores for children using salivary biomarkers. PLoS One (2015) 10:e0138979. doi:10.1371/journal.pone.0138979

75. Abikshyeet P, Ramesh V, Oza N. Glucose estimation in the salivary secretion of diabetes mellitus patients. Diabetes Metab Syndr Obes (2012) 5:149-54. doi:10.2147/DMSO.S32112

76. Agrawal RP, Sharma N, Rathore MS, Gupta VB, Jain S, Agarwal V, et al. Non-invasive method for glucose level estimation by saliva. J Diabetes Metab (2013) 4:1-5. doi:10.4172/2155-6156

77. Twetman S, Nederfors T, Stahl B, Aronson S. Two-year longitudinal observations of salivary status and dental caries in children with insulin-dependent diabetes mellitus. Pediatr Dent (1992) 14:184-8.

78. Kadashetti V, Baad R, Malik N, Shivakumar KM, Vibhute N, Belgaumi U, et al. Glucose level estimation in diabetes mellitus by saliva: a bloodless revolution. Rom J Intern Med (2015) 53:248-52. doi:10.1515/rjim2015-0032

79. Abrão AL, Falcao DP, de Amorim RF, Bezerra AC, Pombeiro GA, Guimarães LJ, et al. Salivary proteomics: a new adjuvant approach to the early diagnosis of familial juvenile systemic lupus erythematosus. Med Hypotheses (2016) 89:97-100. doi:10.1016/j.mehy.2016.02.010

80. Castagnola M, Messana I, Inzitari R, Fanali C, Cabras T, Morelli A, et al. Hypo-phosphorylation of salivary peptidome as a clue to the molecular pathogenesis of autism spectrum disorders. J Proteome Res (2008) 7:5327-32. doi: $10.1021 /$ pr8004088

81. Ngounou Wetie AG, Wormwood KL, Russell S, Ryan JP, Darie CC, Woods AG. A pilot proteomic analysis of salivary biomarkers in autism spectrum disorder. Autism Res (2015) 8:338-50. doi:10.1002/aur.1450

82. Wormwood KL, Aslebagh R, Channaveerappa D, Dupree EJ, Borland MM, Ryan JP, et al. Salivary proteomics and biomarkers in neurology and psychiatry. Proteomics Clin Appl (2015) 9:899-906. doi:10.1002/prca.201400153

83. WHO Fact Sheet. Children: Reducing Mortality (2016). Available from: https://www.who.int/mediacentre/factsheets/fs178/en/

84. Parahitiyawa NB, Scully C, Leung WK, Yam WC, Jin LJ, Samaranayake LP. Exploring the oral bacterial flora: current status and future directions. Oral Dis (2010) 16:136-45. doi:10.1111/j.1601-0825.2009.01607.x

85. Lif Holgerson P, Öhman C, Rönnlund A, Johansson I. Maturation of oral microbiota in children with or without dental caries. PLoS One (2015) 10:e0128534. doi:10.1371/journal.pone.0128534

86. Fabian TK, Fejerdy P, Csermely P. Salivary genomics, transcriptomics, and proteomics: the emerging concept of the oral ecosystem and their use in the early diagnosis of cancer and other diseases. Curr Genomics (2008) 9:11-21. doi:10.2174/138920208783884900

87. Sueki A, Matsuda K, Yamaguchi A, Uehara M, Sugano M, Uehara T, et al. Evaluation of saliva as diagnostic materials for influenza virus infection by PCR-based assays. Clin Chim Acta (2015) 453:71-4. doi:10.1016/j. cca.2015.12.006 
88. Martin ET, Kuypers J, McRoberts JP, Englund JA, Zerr DM. Human bocavirus-1 primary infection and shedding in infants. J Infect Dis (2015) 212:516-24. doi:10.1093/infdis/jiv044

89. de França TR, Carvalho AD, Gomes VB, Gueiros LA, Porter SR, Leao JC. Salivary shedding of Epstein-Barr virus and cytomegalovirus in people infected or not by human immunodeficiency virus 1. Clin Oral Investig (2012) 16:659-64. doi:10.1007/s00784-011-0548-5

90. Cannon MJ, Stowell JD, Clark R, Dollard PR, Johnson D, Mask K, et al. Repeated measures study of weekly and daily cytomegalovirus shedding patterns in saliva and urine of healthy cytomegalovirus-seropositive children. BMC Infect Dis (2014) 14:569. doi:10.1186/s12879-014-0569-1

91. Yamamoto Y, Morooka M, Hashimoto S, Ihra M, Yoshikawa T. Analysis of the shedding of three $\beta$-herpesviruses in urine and saliva of children with renal disease. J Med Virol (2014) 86:505-11. doi:10.1002/jmv.23782

92. Smith RJH, Shearer AE, Hildebrand MS, Camp GV. Deafness and hereditary hearing loss overview. In: Pagon RA, Adam MP, Ardinger $\mathrm{HH}$, Wallace SE, Amemiya A, Bean LJH, et al., editors. GeneReviews ${ }^{\circledR}$. Seattle, WA: University of Washington (1999). Available from: http://www. ncbi.nlm.nih.gov/books/NBK1434/

93. Stern H, Tucker SM. Cytomegalovirus infection in the newborn and in early childhood. Lancet (1965) 2:1268-71. doi:10.1016/S0140-6736(65)92283-X

94. Ross SA, Ahmed A, Palmer AL, Michaels MG, Sánchez PJ, Bernstein DI, et al. Detection of congenital cytomegalovirus infection by real-time polymerase chain reaction analysis of saliva or urine specimens. J Infect Dis (2014) 210:1415-8. doi:10.1093/infdis/jiu263

95. Barzon L, Pacenti M, Berto A, Sinigaglia A, Franchin E, Lavezzo E, et al. Isolation of infectious Zika virus from saliva and prolonged viral RNA shedding in a traveller returning from the Dominican Republic to Italy, January 2016. Euro Surveill (2016) 21(10):30159. doi:10.2807/1560-7917. ES.2016.21.10.30159

96. Barzon L, Pacenti M, Berto A, Sinigaglia A, Franchin E, Lavezzo E, et al. Detection of Zika virus in saliva. J Clin Virol (2015) 68:53-5. doi:10.1016/j. jcv.2015.04.021

97. Brandrzaeg P. Synthesis and secretion of human salivary immunoglobulins. In: Garrett JR, Ekström J, Anderson LC, editors. Glandular Mechanisms of Salivary Secretion: Frontiers of Oral Biology. (Vol. 10), Basel: Karger (1998). p. 167-99.

98. Jayashree S, Bhan MK, Kumar R, Raj P, Glass R, Bhandari N. Serum and salivary antibodies as indicators of rotavirus infection in neonates. J Infect Dis (1988) 158:1117-20. doi:10.1093/infdis/158.5.1117

99. Friedman MG, Segal B, Zedaka R, Sarov B, Margalith M, Bishop R, et al. Serum and salivary responses to oral tetravalent reassortant rotavirus vaccine in newborns. Clin Exp Immunol (1993) 92:194-9. doi:10.111 1/j.1365-2249.1993.tb03379.x

100. Eckstein MB, Brown DW, Foster A, Richards AF, Gilbert CE, Vijayalakshmi P. Congenital rubella in south India: diagnosis using saliva from infants with cataract. BMJ (1996) 312:161. doi:10.1136/bmj.312.7024.161

101. Spicher VM, Bouvier P, Schlegel-Haueter SE, Morabia A, Siegrist CA. Epidemiology of herpes simplex virus in children by detection of specific antibodies in saliva. Pediatr Infect Dis J (2001) 20:265-72. doi:10.1097/ 00006454-200103000-00010

102. Vainio K, Samdal HH, Ånestad G, Wedege E, Skutlaberg DH, Bransdal KT, et al. Detection of measles-and mumps-specific IgG antibodies in paired serum and oral fluid samples from Norwegian conscripts. Eur J Clin Microbiol Infect Dis (2008) 27:461-5. doi:10.1007/s10096-008-0460-3

103. Arora G, Sheikh S, Pallagatti S, Singh B, Singh VA, Singh R. Saliva as a tool in the detection of hepatitis B surface antigen in patients. Compend Contin Educ Dent (2012) 33:174-6.

104. Archibald DW, Johnson JP, Nair P, Alger LS, Hebert CA, Davis E, et al. Detection of salivary immunoglobulin A antibodies to HIV-1 in infants and children. AIDS (1990) 4:417-20. doi:10.1097/00002030-19900500000006

105. Zaka-ur-Rab Z, Abqari S, Shahab T, Islam N, Shukla I. Evaluation of salivary anti-Salmonella typhi lipopolysaccharide IgA ELISA for serodiagnosis of typhoid fever in children. Arch Dis Child (2012) 97:236-8. doi:10.1136/ adc. 2011.300622

106. Belda-Ferre P, Alcaraz LD, Cabrera-Rubio R, Romero H, Simón-Soro A, Pignatelli $\mathrm{M}$, et al. The oral metagenome in health and disease. ISME J (2012) 6:46-56. doi:10.1038/ismej.2011.85

107. Wade WG. Has the use of molecular methods for the characterization of the human oral microbiome changed our understanding of the role of bacteria in the pathogenesis of periodontal disease? J Clin Periodontol (2011) 38 (Suppl 11):7-16. doi:10.1111/j.1600-051X.2010.01679.x

108. Centers for Disease Control. Health, United States, 2015 with Special Feature on Racial and Ethnic Health Disparities. Available from: https://www.cdc.gov/ nchs/data/hus/hus15.pdf

109. Bosker WM, Huestis MA. Oral fluid testing for drugs of abuse. Clin Chem (2009) 55:1910-31. doi:10.1373/clinchem.2008.108670

110. Guinan T, Ronci M, Kobus H, Voelcker NH. Rapid detection of illicit drugs in neat saliva using desorption/ionization on porous silicon. Talanta (2003) 99:791-8. doi:10.1016/j.talanta.2012.07.029

111. Cámpora P, Bermejo AM, Tabernero MJ, Fernandez P. Quantitation of cocaine and its major metabolites in human saliva using gas chromatography-positive chemical ionization-mass spectrometry (GC-PCI-MS). J Anal Toxicol (2003) 27:270-4. doi:10.1093/jat/27.5.270

112. Fisher DS, Patridge SJ, Handley SA, Couchman L, Morgan PE, Flanagan RJ. LC-MS/MS of some atypical antipsychotics in human plasma, serum, oral fluid and haemolysed whole blood. Forensic Sci Int (2013) 229:145-50. doi:10.1016/j.forsciint.2013.03.021

113. Sood SP, Green VI, Vieva LL. Routine methods in toxicology and therapeutic drug monitoring by high-performance liquid chromatography. VI: a rapid microscale method for determination of caffeine in plasma and saliva. Ther Drug Monit (1989) 11:361-4. doi:10.1097/00007691-19890500000023

Conflict of Interest Statement: The authors declare that the research was conducted in the absence of any commercial or financial relationships that could be construed as a potential conflict of interest.

Copyright (C) 2017 Hassaneen and Maron. This is an open-access article distributed under the terms of the Creative Commons Attribution License (CC BY). The use, distribution or reproduction in other forums is permitted, provided the original author(s) or licensor are credited and that the original publication in this journal is cited, in accordance with accepted academic practice. No use, distribution or reproduction is permitted which does not comply with these terms. 